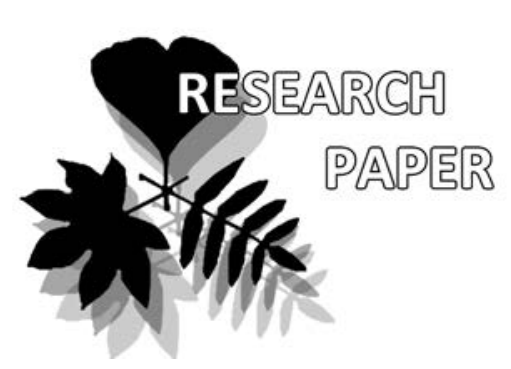

\title{
Fruit micromorphology in the Umbelliferae of the Russian Far East
}

\author{
Tatiana A. Ostroumova
}

Tatiana A. Ostroumova

e-mail: ostroumovata@gmail.com

Botanical Garden, Lomonosov Moscow state University, Russia

Manuscript received: 06.11.2017 Review completed: 14.02.2018 Accepted for publication: 03.04.2018 Published online: 18.04.2018

\begin{abstract}
A B S T R A C T
Fruit micromorphology of all 65 native species of the Umbelliferae of the Russian Far Easrt was studied. We described cell arangement, cell form, fine relief of cell wall (cuticular foldings), epicuticular wax, stomata, crystals. Scanning electron microscope (SEM) also gave information on the inner structure of plant organs. We discuss the diversity of micromorphological characters and their taxonomic value. Some new diagnostic characters for the genera Kitagawia (areas with rugulate cuticle), Ligusticum and Magadania (large convex exocarp cells) were revealed. K e yw o r d s : Umbelliferae, taxonomy, identification, SEM
\end{abstract}

\section{P E 3 Ю M E}

Остроумова Т.А. Микроморфология плодов зонтичных российского Аамьнего Востока. Изучена микроморфология плодов всех 65 виАов зонтичных Российского Аальнего Востока. Мы описываем расположение клеток, их форму, скульптуру кутикулы, эпикутикулярный воск, устьица, кристал ы. С помощью сканирующего электронного микроскопа возможно также изучать внутреннюю структуру органов. Обсуждается разнообразие микроморфологических признаков и их значение Аля систематики. Аля некоторых родов выяв ены новые диагностические признаки: участки с морщинистой кутикулой у Kitagawia, крупные выпуклые клетки экзокарпа у Ligusticum и Magadania.

КАючевые слова: Umbelliferae, таксономия, определение, сканирующая электронная микроскопия

\section{N TRODUCTION}

Fruit micromorphological studies in the Umbelliferae showed an importance of these characters for taxonomy in the examples of genera Torilis (Heywood \& Dakshini 1971), Geocaryum (Engstrand 1973), Trinia (Fedoronchuk 1983), Eryngium (Tamamschjan \& Pimenov 1987), Tordylium (Ai-Eisawi \& Jury 1988), Pastinaca (Menemen \& Jury 2001), Lichtensteinia (van Wyk \& Tilney 2007), Rhabdosciadium (Duran et al. 2010), Bilacunaria (Duran et al. 2011), Diplotaenia (Duran et al. 2015), Taeniopetalum (Ostroumova et al. 2016), Peucedanum s. str. (Yildiri \& Duman 2017). Studies cover mostly Europe, North and South Africa, Turkey, the Caucasus. There are few publications on Umbelliferae of East Asia, for example, Acronema (Wang et al. 2013). We studied fruit micromorphology of almost all the species of Russia and now present an analysis of species of the Russian Far East (Amur, Magadan, Sakhalin regions, Khabarovsk, Primorye and Kamchatka territories and Chukotka Autonomous District). There are 65 native Umbelliferae species in this region.

SEM images provide an opportunity to interpret our observation with an optic stereomicroscope and find new data for plant identification and taxonomic work. For example, the exocarp composed of large convex cells has the appearance of a shiny, grainy surface under the stereomicroscope while the exocarp of small cells is matte and not grainy. SEM images helped to distinguish between hair types and notice small projections. We used these characters in our identification keys (Pimenov \& Ostroumova 2012, Plunkett et al. 2018). Fine details $(1-5 \mu \mathrm{m})$ can also provide important material for taxonomy (e.g. Fedoronchuk 1983).

\section{MATERIAL AND METHODS}

We studied the fruits of all the native species of the Russian Far East. The fruits were collected during field work, in the living plant collection of MSU Botanical garden, and in some herbaria. Fruit samples are stored in the carpological collection in the Botanical garden of the Lomonosov Moscow State University.

SEM studies of fruits were made with a CamScan S-2 (accelerating voltage $15 \mathrm{kV}$ and working distance $56 \mathrm{~mm}$ ) at the magnification of 15-3000x. Dry fruits were placed on aluminium stubs and sputter-coated with gold or gold-palladium to a thickness of ca. $25 \mathrm{~nm}$.

In our previous publications we compiled the dictionary for characters and character states for the Umbelliferous fruits (Ostroumova et al. 2010, 2011). Basic points for description of SEM images were published by Barthlot \& Ehler (1977) and Barthlot (1981), for the fine relief of the cell wall we used palynological terminology where possible (Hesse et al. 2009). 


\section{Material used for micromorphological investigation}

We studies species listed below, from different sources marked as following: BG MSU - fruits harvested on the living plant collection of MSU Botanical garden; CARP fruits from natural habitats in the carpological collection of MSU Botanical garden; MW, MHA, LE etc. - fruits from herbarium collections. The species of geographic regions outside the Russian Far East are marked with asterisk. Nomencalture is given after Pimenov \& Ostroumova (2012) and Pimenov (2017).

Aegopodium alpestre Ledeb. MW0105723, MW0105704;

Angelica anomala Avé-Lall. BG MSU 1982-077;

Angelica cincta $\mathrm{H}$. Boissieu BG MSU 1975-363;

Angelica czernaevia (Fisch. \& C.A. Mev.) Kitag., CARP Primorsky terr. Krivoy Klyuch, 25.09.1960 Pimenov;

Angelica dahurica (Fisch. ex Hoffm.) Benth. \& Hook.f. CARP Primorsky terr. 04.09.1963 Pimenov;

Angelica decursiva (Miq.) Franch. \& Sav. CARP Primorsky terr. 15.10.1963 Pimenov;

Angelica edulis Miyabe (G) IX.1904 Faurie 6276;

Angelica genuflexa Nutt. ex Torr. \& A. Gray CARP Kamchatka, Dolinskoye 20.09.1961 Pimenov;

Angelica gmelinii (DC.) Pimenov CARP Kunashir Isl., Cape Stolbchaty 19.09.1983 Pimenov, Kljuykov;

Angelica sachalinensis Maxim. BG MSU 1983-137, 1989-766;

Angelica saxatilis Turcz. (LE) Ayan;

Angelica ursina (Rupr.) Maxim. CARP Sachalin Isl., Lugovoye 20.09.1963 Pimenov;

Anthriscus sylvestris (L.) Hoffm MW0107236, MW0107161, MW0855938;

Bupleurum atargense Gorovoj MW0106825;

Bupleurum euphorbioides Nakai, MW0106589;

Bupleurum komarovianum Lincz CARP BG Vladivostok 561;

Bupleurum longiradiatum Turcz. Kunashir Isl., Cape Stolbchaty 19.09.1982 Pimenpv \& Kljuykov;

Bupleurum scorzonerifolium Willd., MW0106158;

Bupleurum sibiricum Vest MW0106143;

Bupleurum triradiatum Adams ex Hoffm MW0106056; MW0106104;

Cicuta virosa L., BG MSU 1976-460;

Cnidium cnidiifolium (Turcz.) Schischk MW0118995, MW0118975;

Cnidium dauricum (Jacq.) Turcz. ex Fisch. \& C.A. Mey CARP Transbaikal Terr., Sosnyak, 23.08.1993 Pimenov, Vasilieva;

Cnidium monnieri (L.) Cusson ex Jussieu, (MHA) Primorsky Terr., 13.09.1960 Schreter, Pimenov;

Conioselinum chinense (L.) Britton, Sterns \& Poggenb (MHA) Chabarovsk Terr., 06.090.1967 Khokhryakov et al.;

Conioselinum smithii (H. Wolff) Pimenov \& Kljuykov CARP Primorsky terr., Sopka Skalistaya 15.11.1983 Korkishko, MW0118414;

Cryptotaenia japonica Hassk BG MSU 1989-430;

Glehnia littoralis F. Schmidt ex Miq., (MHA) Primorsky Terr. 18.09.1967 Khokhryakov; (MHA) Sakhalin Isl. 22.09.1960. Egorova, Voroshilov 10025;

Halosciastrum melanotilingia (H. Boissieu) Pimenov \& V.N. Tikhom (MHA) Primorsky Terr., Natural Reserve Kedrovava Pad 30.09.1956 Voroshilov 8202

Heracleum dissectum Ledeb. MW0864582, MW0117102, MW0117087;

Heracleum lanatum Michx., MW0117036; MW0117041;

Kitagawia eryngiifolia (Kom.) Pimenov CARP BG Vladivostok, MW0117396;

Kitagawia komarovii Pimenov MW0117382, MW 0117392;

Kitagawia litoralis (Vorosch. \& Gorovoj) Pimenov (MHA) Primorsky Terr. 29.10.1977 Makarov;

Kitagawia macilenta* $\mathrm{P} 02272025$

Kitagawia praeruptora* (K) China, Shansi Prov, Clements 6292;

Kitagawia terebinthacea (Fisch. ex Trev.) Pimenov CARP Transbaikalia, Ishata 23.09.1963 Pimenov;

Ligusticum scoticum L., BG MSU 1976-500

Magadania olaensis (Gorovoj \& N.S. Pavlova) Pimenov \& Lavrova (MHA) Magadan reg. 10.08.1971 Mazurenko, Khokhryakov;

Magadania victoris (Schischk.) Pimenov \& Lavrova (MHA) near Magadan, 21.08.1968 Grichuk;

Oenanthe javanica (Blume) DC., [1983] BG MSU 1980-294;

Orumbella macounii (J.M. Coult. \& Rose) J.M. Coult. \& Rose UC1579153 Alaska Mt. Makinley Nat.Park 05.08.1950 Harold \& Virginia Bailey 4978;

Osmorhiza aristata (Thunb.) Rydb., CARP Altai, watershed between Biya and Inya rivers 05.08.1990 Pimenov, Vasilieva; Ostericum grosseserratum (Maxim.) Kitag W0118075;

Ostericum maximowiczii (F. Schmidt ex Maxim.) Kitag CARP Primorsky terr. , Primorskaya station 10.10.1963 Pimenov;

Ostericum sieboldii (Miq.) Nakai CARP Lukyanovka 20.09.1964 Pimenov;

Ostericum tenuifolium (Pall. ex Spreng.) Chu You Chang MW0117814, MHA Butyatia, Mondy, 15.08.1963 Flyanskaya et al.;

Ostericum viridiflorum (Turcz.) Kitag CARP 1964 Pimenov, MW 0117740;

Pachypleurum alpinum Ledeb CARP Buryatia, Nilova Pustyn,10.08.1992 Pimenov, Vasilieva; CARP Alyay, Karakolskie Lakes 06.08.1990;

Peucedanum officinale* L. BG MSU 1987-283;

Peucedanum ruthenicum* M.Bieb. BG MSU 1993-011;

Phlojodicarpus komarovii Gorovoj (LE) Prov. Chabarovsk Dokturovskij 1481;

Phlojodicarpus sibiricus (Fisch. ex Spreng.) Koso-Pol., (NS) Transbaikalia, Nerchinskiy Zavod 11.08.1988 Vlasova 544; BG MSU 1975-375.

Phlojodicarpus villosus (Turcz. ex Fisch. \& C.A. Mey.) Ledeb CARP Sayan Mts., the border of Khakasia and Tyva, Grigorieva 08-2004;

Pimpinella thellungiana H. Wolff MW0105768;

Pleurospermum uralense Hoffm Chelvabinsk reg., $5 \mathrm{~km} \mathrm{~S}$ of Zlatoust 20.09.1979 Kljuykov; Chelyabinsk reg., Serafimov Verkh, 22.09.1979 Kljuykov;

Rupiphila tachiroei (Franch. \& Sav.) Pimenov \& Lavrova Primorsky terr., Dalnegorsk 20.08.2015 Degtyareva;

Sanicula chinensis Bunge Primorsky terr., Kedrovaya Pad Natural reserve, 01.10.1960 Pimenov;

Sanicula rubriflora F. Schmidt ex Maxim. BG MSU;

Saposhnikovia divaricata (Turcz.) Schischk. CARP Tamamshjan; MW0105506;

Schulzia crinita (Pall.) Spreng., CARP Irkutsk reg., Chersky Mt. 19.08.2001 Shepotkin;

Seseli condensatum (L.) Rchb.f BG MSU 1974-059;

Seseli seseloides (Fisch. \& C.A.Mey. ex Turcz.) M. Hiroe CARP Tranbaikalia Terr., 01.09.1958 Tikhomirov;

Sium suave Walter CARP Transbaikalia terr., Sosnyak station 23.08.1993, Pimenov, Vasilieva;

Sium tenue (Kom.) Kom. Primorsky Terr., Promorskaya station 01.10.1960 Pimenov;

Sphallerocarpus gracilis (Besser ex Trev.) Koso-Pol BG MSU 1993-869; BG MSU 1995-117; MW0107294;

Spuriopimpinella calycina (Maxim.) Kitag (MHA) Ptimorsky terr. 06.09.1958 Egorova;

Tilingia ajanensis Regel \& Tiling BG MSU 1983-148; MW0118842; (MHA) Khabarovsk terr., 29.08.1981 Gotvansky et al. № 6500;

Torilis japonica (Houtt.) DC. MW0452693, MW0452671.

\section{RESULTS AND DISCUSSION}

\section{Pubescence}

Hair types, when present, are rather diverse. Heracleum dissectum (Fig. 1bc), H. lanatus, Glehnia littoralis (Fig. 1a), Phlojodicarpus komarovii and P. villosus have unicellular long, ribbon-like thin-walled hairs. In Heracleum and Glebnia hair fine relief is smooth or sparsely striate, and in Pblojodicarpus, it is rugulate and tuberculate. Hair length in the Heracleum and Phlojodicarpus species is up to $0.5 \mathrm{~mm}$ and in Glehnia, up to $1 \mathrm{~mm}$. The ovary in $H$. dissectum is densely pubescent; afterwards the fruit enlarges, some hairs fall away, and the mature fruit became almost glabrous.

In Anthriscus, Osmorbiza, Pachypleurum, Seseli, Torilis, and in some samples of Kitagawia komarovii, hairs are thick- 

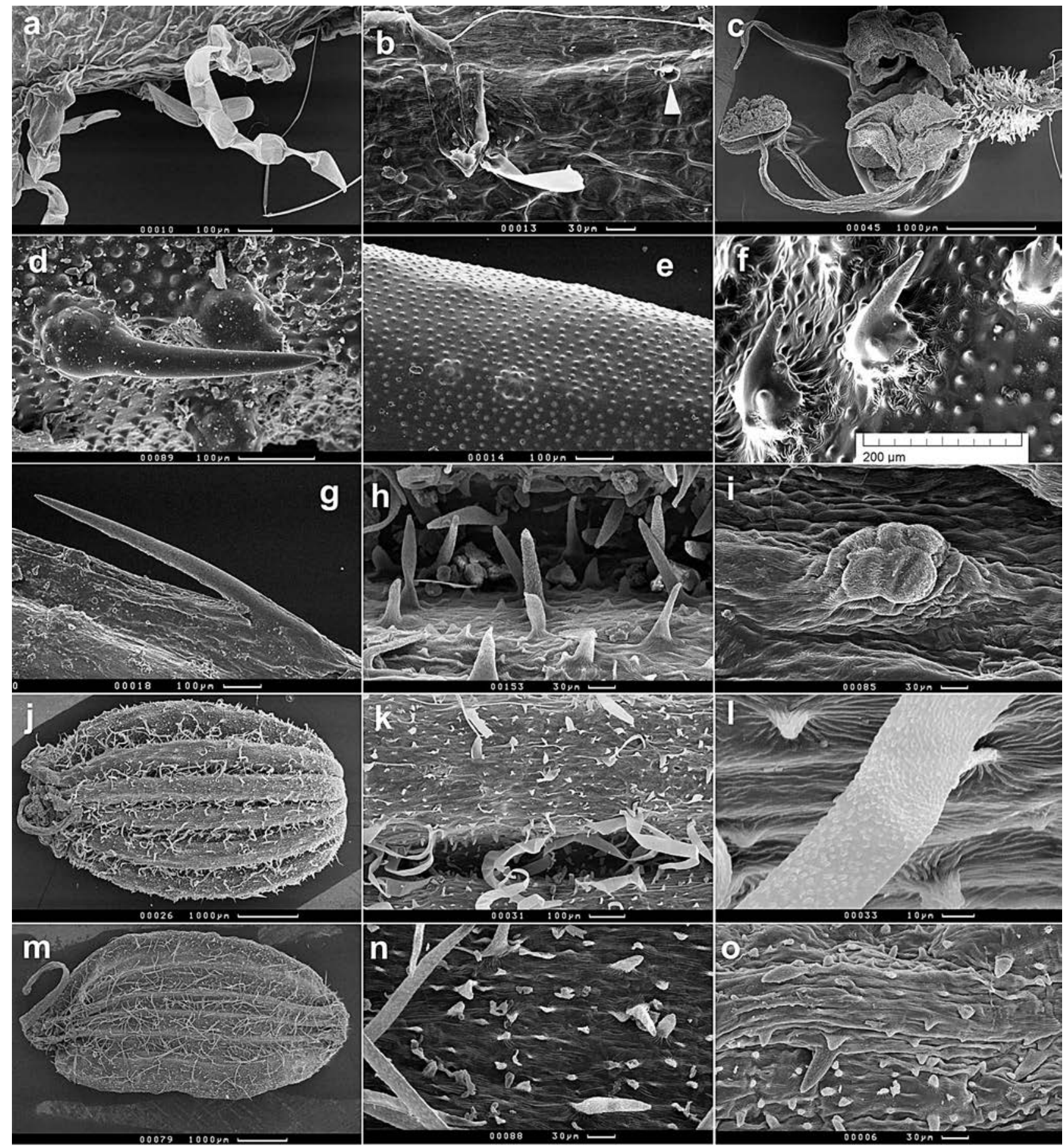

Figure 1 Pubescence: a - Glebnia littoralis, ribbon-like thin-walled hairs; b, c - Heracleum dissectum (b - solitary ribbon-like thin-walled hairs, arrowhead - a base of a fallen hair; c - a flower with densely pubescent ovary); d, e, f - Anthriscus sylvestris ( $\mathrm{d}$ - a thick-walled hair with a multicellular base; $\mathrm{e}-\mathrm{a}$ glabrous fruit, cell borders inconspicuous, the surface with small dome-shaped bulges; $\mathrm{f}-\mathrm{a}$ fruit after soaking in acetone, epicuticular wax modified); $\mathrm{g}$ - Osmorrhiza aristata, a thick-walled hair with a multicellular base; $\mathrm{h}$ - Pachypleurum alpinum, tiny sharp projections and hairs of variable length; $\mathrm{i}$ - Saposhnikovia divaricata, a multicellular projection; $\mathrm{j}, \mathrm{k}, \mathrm{l}$ - Pblojodicarpus villosus ( $\mathrm{j}$ - a whole fruit; $\mathrm{k}$ - tiny sharp projections and hairs of variable length; 1 - a hair with tuberculate surface); $\mathrm{m}, \mathrm{n}$ - Seseli condensatum ( $\mathrm{m}$ - a whole fruit; $\mathrm{n}$ - tiny sharp projections and hairs of variable length); o - Seseli seseloides, tiny sharp projections and hairs of variable length

walled with rugulate or tuberculate surface. Phlojodicarpus komarovii and $P$. villosus, along with ribbon-like hairs, have hard thick-walled ones. Anthriscus sylvestris (Fig. 1d,e,f) has either pubescent or glabrous fruits, in Siberia and Far East fruits being usually pubescent. Anthriscus sylvestris and Osmorbiza ariastata (Fig. 1g) belong to the tribe Scandiceae, they have hairs with multicellular bases, hairs being appressed upward. This hair type is also known in another genera of
Scandiceae, which inhabit the western part of the tribe area, Myrrbis, Myrrhoides, and Scandix. The tribe Scandiceae is one of the few tribes that has proved to be monophyletic on the basis of molecular data (Spalik et al. 2001, Downie et al. 2010) and micromorphological characters are in accordance with other data sets. Torilis japonica of the tribe Caucalideae has appressed hairs on multicellular bases on primary mericarp ribs. 
Angelica genuflexa and $A$. ursina have sparse and very short $(20-30 \mu \mathrm{m})$ hairs that are not visible in stereomicroscope at x20; their fruits are usually described as glabrous.

The whole spectrum of hair size from tiny sharp projections to the usual 50-100 (500) $\mu \mathrm{m}$ long hairs are present in Pachypleurum alpinum (Fig. 1h), Phlojodicarpus villosus (Fig. 1j,k,l), and Sesel condensatum (Fig. 1m,n). It is interesting to mention that the geographic areas of these species are broad and include the Arctic. A similar set of hairs and projections are also found on the fruits of Phlojodicarpus komarovii (an endemic species of the Russian Far East) and Seseli seseloides (Fig. 1o; distributed in the South of the Russian Far East, in Mongolia, China, and the Korean peninsula).

Exozoochoric fruits of Sanicula (Fig. 2a,b) and Torilis (Fig. 2c,d) are covered with multicellular hooked spines, the spines in Sanicula are smooth, and in Torilis their surface is densely covered with sharp prickles 10-20 $\mu \mathrm{m}$ long.

The mature fruits of Saposhnikovia (Fig. 1i) have multicellular bulges up to $100 \mu \mathrm{m}$ high, their tops being com- posed of one to three large cells, 30-70 $\mu \mathrm{m}$ in diam. each, and bases being multicellular of small cells. The top cells have rugulate surface, and the basal cells are striate.

\section{Characters of exocarp cells}

Cell form (Table 1), primary sculpture after Barthlott \& Ehler (1977). The ridge of primary rib is rather uniform, it is usually covered with long cells or rows of short cells, or it is longitudinally sulcate. When the fruits are compressed dorsally and have winged marginal ribs, the wing edge is usually covered with isodiametric cells with raised borders and concave periclinal walls (Angelica, Heracleum (Fig. 3e), Kitagawia). The micromorphology of valleculas is more divers and often specific to taxa. We therefore focus primarily on the sculpture of valleculas and rib sides.

Cell borders are often inconspicuous, and the fruit surface is undulate (Angelica edulis, Osmorbiza aristata, Orumbella macounii (Fig. 3a), Seseli seseloides) rugate (Angelica cincta, A. czernaevia, A. ursina, Bupleurum komarovianum, B. longiradiatum, Cicuta virosa, Kitagawia eryngïfolia, K. litoralis, Oenanthe

Table 1. Characters of exocarp cells

\begin{tabular}{|c|c|c|c|c|c|c|c|c|c|c|c|c|c|}
\hline \multirow[b]{2}{*}{ Species name } & \multicolumn{2}{|c|}{ Cell size } & \multicolumn{2}{|c|}{$\begin{array}{c}\text { Cell } \\
\text { arrangement }\end{array}$} & \multicolumn{2}{|c|}{$\begin{array}{c}\text { Cell } \\
\text { outlines }\end{array}$} & \multicolumn{2}{|c|}{ Cell borders } & \multicolumn{5}{|c|}{ Outer periclinal walls } \\
\hline & 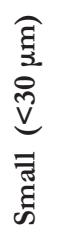 & 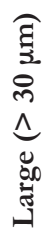 & 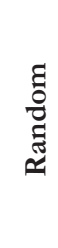 & $\underbrace{\infty}_{=}$ & 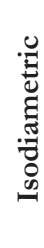 & $\begin{array}{l}0 \\
\stackrel{0}{0} \\
\frac{0}{0} \\
0 \\
0\end{array}$ & 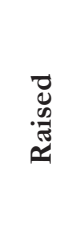 & $\underset{\tilde{D}}{\frac{E}{J}}$ & $\frac{\vec{\pi}}{\text { II }}$ & ن & 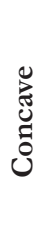 & 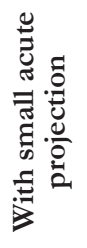 & 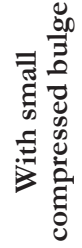 \\
\hline Aegopodium alpestre & + & & & + & & + & & + & + & + & & & \\
\hline Angelica anomala & + & & + & & + & + & + & & + & & + & & + \\
\hline Angelica daburica & + & + & & + & & + & & + & + & & & & \\
\hline Angelica genuflexa & + & & & + & + & + & & + & + & & + & & \\
\hline Angelica saxatilis & + & & & + & + & & & + & + & & + & & + \\
\hline Bupleurum atargense & + & & + & & + & + & & + & & + & & & \\
\hline Bupleurum euphorbioides & + & & + & & + & & + & + & & + & + & & \\
\hline Bupleurum scorzonerifolium & + & & & + & + & & + & & & & + & & \\
\hline Bupleurum sibiricum & + & & + & + & + & & & + & & + & & & \\
\hline Bupleurum triradiatum & + & & + & & + & + & & + & & + & & & \\
\hline Cnidium cnidiifolium & + & & & + & + & & + & & & & + & & \\
\hline Cnidium monnieri & + & & + & & + & & + & & & & + & & \\
\hline Conioselinum chinense & + & & & + & + & + & + & + & + & & & & \\
\hline Cryptotaenia japonica & + & & & + & + & & + & & & & + & & \\
\hline Glebnia littoralis & & + & + & & + & & + & & + & & & & \\
\hline Halosciastrum melanotilingia & & + & + & & + & & + & + & & + & & & \\
\hline Heracleum dsssectum & + & & + & & + & & + & & & & + & & \\
\hline Heracleum lanatum & + & & + & & + & & + & & + & & & & \\
\hline Ligusticum scoticum & & + & + & & + & & & + & & + & & & \\
\hline Magadania olaensis & & + & + & & + & + & & + & & + & & + & \\
\hline Magadania victoris & & + & + & & + & & & + & & & & & + \\
\hline Ostericum grosseserratum & & + & + & + & + & & & + & & + & & & + \\
\hline Ostericum maximowiczüi & & + & + & & + & & & + & & + & & & \\
\hline Ostericum sieboldii & & + & + & & + & & & + & & + & & & \\
\hline Ostericum tenuifolium & & + & + & & + & + & & + & & + & & & \\
\hline Ostericum viridiflorum & & + & + & & + & & & + & & + & & & \\
\hline Pachypleurum alpinum & + & + & + & & + & + & & + & + & & & + & \\
\hline Phlojodicarpus sibiricus & + & + & + & + & + & & + & & + & & & & \\
\hline Pleurospermum uralense & & + & + & & + & & & + & & + & & & \\
\hline Rupiphila tachiroei & + & & + & & + & & + & & + & & + & & \\
\hline Sanicula chinensis & + & & + & & + & & + & & & & + & & \\
\hline Sanicula rubriflora & + & & + & + & + & & & + & & + & & & \\
\hline Saposhnikovia divaricata & & + & + & + & + & + & & + & & + & & + & \\
\hline Sium suave & + & & & + & + & + & + & & + & & & & \\
\hline Sphallerocarpus gracillis & + & & + & & + & & & + & & + & & & \\
\hline Tilingia ajanensis & & + & + & & + & & & + & & + & & & \\
\hline Torilis japonica & + & & & + & + & & & + & & & + & & \\
\hline
\end{tabular}



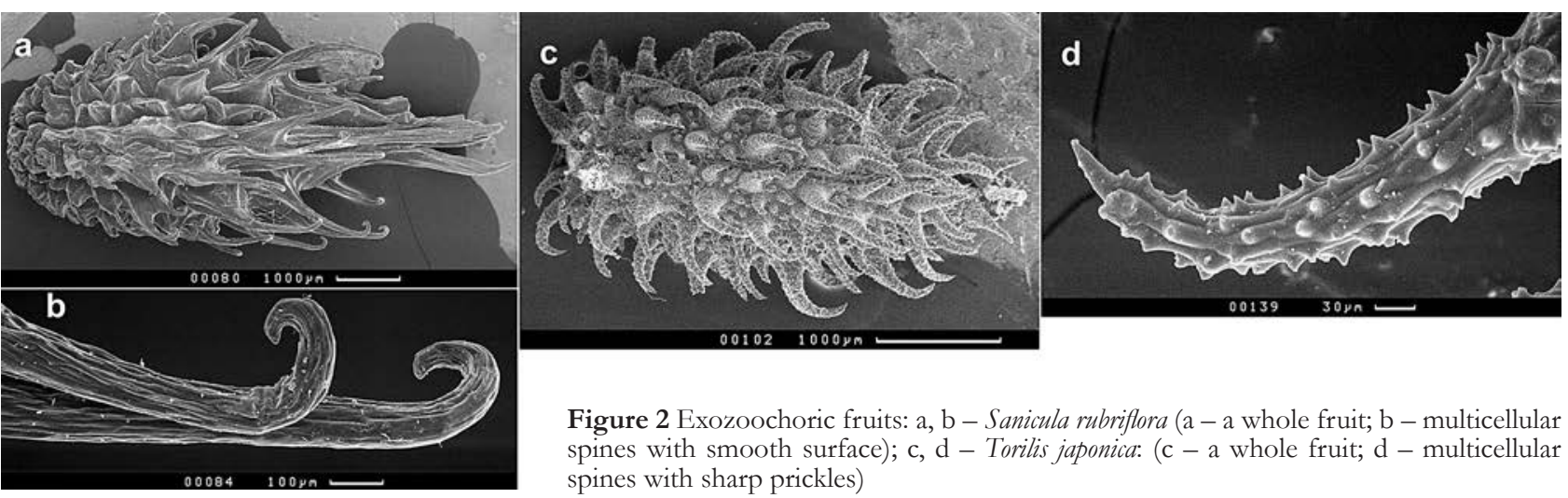

Figure 2 Exozoochoric fruits: a, b - Sanicula rubriflora ( $\mathrm{a}$ - a whole fruit; $\mathrm{b}$ - multicellular spines with smooth surface); c, d - Torilis japonica: (c - a whole fruit; d - multicellular spines with sharp prickles)
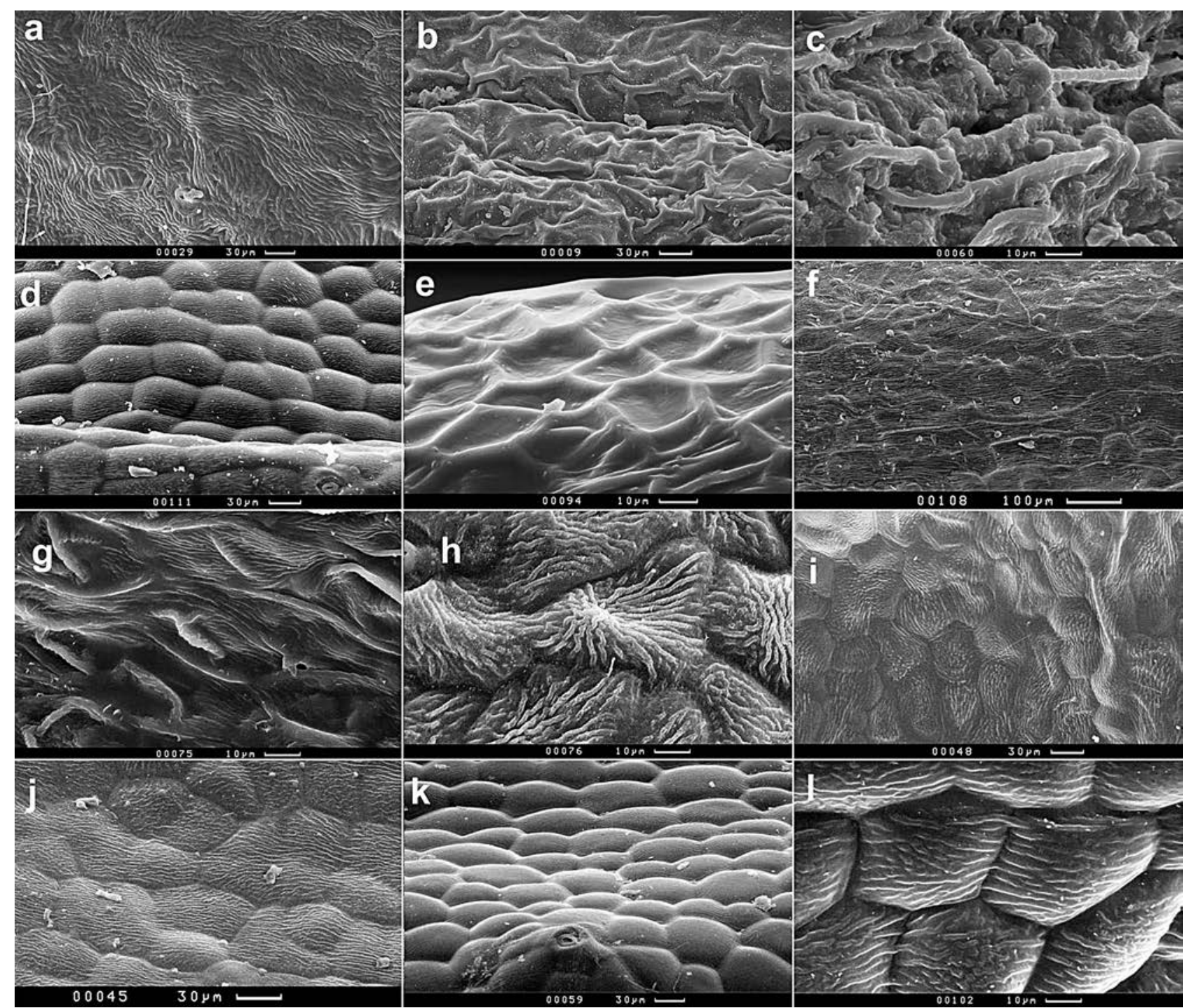

Figure 3 Cell arrangement and form: $\mathrm{a}-\mathrm{c}$ - cell borders inconspicuous ( - Orumbella macounii, fruit surface undulate; $\mathrm{b}-$ Pimpinella thellungiana, fruit surface rugate; c - Cicuta virosa, fruit surface foveolate-tuberculate); $\mathrm{d}-\mathrm{l}$ - cell borders distinct (d - Ostericum viridiflorum, cells large, arranged in rows, cell borders sunken, cuticle rugulate; e - Heracleum lanatum, marginal wing, cells arranged at random, cell borders raised, outer walls concave, cuticle smooth; $\mathrm{f}$ - Phlojodicarpus sibiricus, cell borders raised, outer walls flat, cuticle striate; $\mathrm{g}$ - Angelica anomala, cell borders raised, outer walls with obtuse compressed projections, cuticle striate and rugulate; $\mathrm{h}$ - Magadania olaensis, cell borders sunken, outer wall with conical projection, cuticle striato-knotted; i-l - large cells with convex outer walls and rugulate cuticle: i - Halosciastrum melanotilingia, $\mathrm{j}$ - Ligusticum scoticum, $\mathrm{k}$ - Pleurospermum uralense, $\mathrm{l}$ - Tilingia ajanensis)

javanica, Pimpinella thellungiana (Fig. 3b), Schulza crinita, Sium tenue, Spuriopimpinella calycina), sulcate (Pblojodicarpus komarovii), or foveolate-tuberculate (Angelica decursiva, A. gmelinii, A. sachalinensis, Cicuta virosa (Fig. 3c), Cnidium dauricum, Conio- selinum smithii, Kitagawia komarovii, K. terebinthacea). Sometimes fruit surface without cell borders has small domeshaped bulges (Anthriscus sylvestris), acute conical projections (Kitagawia komarovii, Phlojodicarpus komarovii, P. villosus, Seseli 
Table 2. Cuticlar sculpture and epicuticular wax

\begin{tabular}{|c|c|c|c|c|c|c|c|c|c|c|c|}
\hline \multirow[b]{2}{*}{ Species name } & \multicolumn{7}{|c|}{ Cuticular foldings } & \multicolumn{4}{|c|}{$\begin{array}{c}\text { Epicuticular } \\
\text { wax }\end{array}$} \\
\hline & 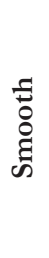 & 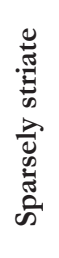 & 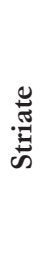 & 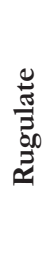 & 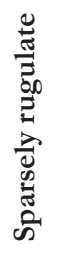 & 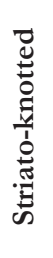 & 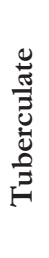 & 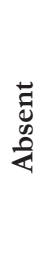 & 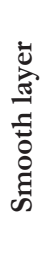 & 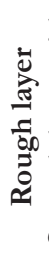 & 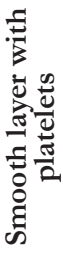 \\
\hline Aegopodium alpestre & & + & & & + & & & & & & \\
\hline Angelica anomala & & + & + & + & & & & + & & & \\
\hline Angelica cincta & & & + & + & & & & + & & & \\
\hline Angelica czernaevia & & + & & & & & & + & + & + & \\
\hline Angelica daburica & & & + & + & & & & + & & & \\
\hline Angelica decursiva & & + & & & & & & + & + & + & \\
\hline Angelica edulis & & & + & & & & & + & & + & \\
\hline Angelica genuflexa & & + & + & & + & & & + & & & \\
\hline Angelica gmelinii & + & & & & & & & & + & & \\
\hline Angelica sachalinensis & & & + & + & & & & & & & + \\
\hline Angelica saxatilis & & + & + & & & & & + & & & \\
\hline Angelica ursina & & + & + & + & & & & + & & & \\
\hline Anthriscus sylvestris & + & & & & & & & & + & & \\
\hline Bupleurum atargense & + & & & & & & & & + & + & + \\
\hline Bupleurum euphorbioides & + & & & & & & & & + & + & + \\
\hline Bupleurum komarovianum & + & & & & & & & & + & & + \\
\hline Bupleurum longiradiatum & + & & & & & & & & + & & + \\
\hline Bupleurum scorzonerifolium & + & & & & & & & & + & & + \\
\hline Bupleurum sibiricum & + & & & & & & & & + & & + \\
\hline Bupleurum triradiatum & + & & & & & & & & & & + \\
\hline Cicuta virosa & + & & & & & & & + & & & \\
\hline Cnidium cnidïfolium & & + & & & + & & & + & & & \\
\hline Cnidium dauricum & & + & & & + & & & + & & & \\
\hline Cnidium monnieri & + & & & & & & & & + & + & \\
\hline Conioselinum chinense & & + & & & + & & & + & & & \\
\hline Conioselinum smithii & & + & & & & & & + & & & \\
\hline Cryptotaenia japonica & + & + & & & & & & & + & & + \\
\hline Glehnia littoralis & + & & & & & & & & & & + \\
\hline Halosciastrum melanotiling & & & & & + & & & + & & & \\
\hline Heracleum dsssectum & + & + & + & & & & & + & & & \\
\hline Heracleum lanatum & + & + & & & & & & + & & & \\
\hline Kitagawia eryngiifolia & + & + & & + & & & & + & & & \\
\hline Kitagawia komarovii & & + & + & & + & + & & + & & & \\
\hline Kitagawia litoralis & & + & & + & & & & + & & & \\
\hline Kitagawia terebinthacea & & + & + & + & & & & + & & & \\
\hline Ligusticum scoticum & & & & + & & & & + & & & \\
\hline Magadania olaensis & & & & + & & + & & + & & & \\
\hline Magadania victoris & & & & + & & & & + & & & \\
\hline Oenanthe javanica & + & + & + & & & & & + & & & \\
\hline Orumbella macounii & & & + & + & & & & + & & & \\
\hline Osmorbiza aristata & & & + & & & & & & & + & \\
\hline Ostericum grosseserratum & & & & + & & & & + & & & \\
\hline Ostericum maximowiczii & & & & + & & & & + & & & \\
\hline Ostericum sieboldii & & + & & + & & & & + & & & \\
\hline Ostericum tenuifolium & & & & + & + & & & + & & & \\
\hline Ostericum viridiflorum & & & & + & & & & + & & & \\
\hline Pachypleurum alpinum & & + & + & & & + & & + & & & \\
\hline Phlojodicarpus komarovii & & & + & & & + & & + & & & \\
\hline Phlojodicarpus sibiricus & & + & + & + & & & & + & & & \\
\hline Phlojodicarpus villosus & & & + & & & + & & + & & & \\
\hline Pimpinella thellungiana & + & & & & & & & & & & + \\
\hline Pleurospermum uralense & & + & & & + & & & + & & & \\
\hline Rupiphila tachiroei & & & + & + & & & & + & + & & \\
\hline Sanicula chinensis & & & & + & & & & + & & & \\
\hline Sanicula rubriflora & & & & & & & + & & + & & \\
\hline Saposhnikovia divaricata & & & + & + & & + & & + & & & \\
\hline Schulza crinita & & & + & & & & & + & & & \\
\hline Seseli condensatum & & + & & & & + & & + & & & \\
\hline Seseli seseloides & & & + & & & + & & + & & & \\
\hline Sium suave & + & & & & + & & & + & & & \\
\hline Sium tenue & + & + & & & & & & & + & & \\
\hline Sphallerocarpus gracillis & & + & & & + & & & + & & & \\
\hline Spuriopimpinella calycina & & + & & & & & & + & & & \\
\hline Tilingia ajanensis & & & & + & & & & + & & & \\
\hline Torilis japonica & & & & + & & & & + & & & \\
\hline
\end{tabular}

condensatum, S. seseloides), or obtuse compressed projections (Kitagawia eryngïfolia, K. komarovii, K. litoralis) The foveolate-tuberculate surface most likely occurs when thin outer wall is appressed to dry intracellular content.

Cells are conspicuous all over the fruits in the genera Halosciastrum, Ligusticum s. str., Magadania, Ostericum, Pleurospermum, Sanicula, Tilingia, and in Angelica daburica. In some species the cells are visible in some areas only, and conspicuous cell borders are lacking on the rest of fruit surface. We described the cell form when we could find an area of 20 or more cells with conspicuous borders.

If visible, the cells are arranged in rows (Fig. 3d) or at random (Fig. 3e), and the cell borders are raised (Fig. 3e,f,g) or sunken (Fig. 3d,h-l) and always straight in the species under discussion. The outer periclinal walls are concave (Fig. 3e), flat (Fig. 3f), convex (Fig. 3d,h $-\mathrm{l}$ ), and with acute (Fig. $1 \mathrm{~h}, \mathrm{k}, \mathrm{n}, \mathrm{o})$ or obtuse (Fig. 3g) projection. In Halosciastrum (Fig. 3i), Ligusticum s. str. (Fig. 3j), Magadania (Fig. 3h), Ostericum (Fig. 3d), Pleurospermum (Fig. 3k), and Tilingia (Fig. 31) exocarp cells are large, $>30 \mu \mathrm{m}$. Conspicuous, solid, convex exocarp cells are attributed with the above mentioned genera as well as $A u$ lacospermum, Taeniopetalum and Hansenia (incl. Nothopterygium) from other regions.

\section{Cuticular sculpture and epicuticular wax}

The fine relief of the cell wall (the secondary sculpture, Table 2), is smooth, striate (Fig. 4a), sparsely striate, rugulate (Fig. 4b), sparsely rugulate, tuberculate (Fig. 4c) or striato-knotted (Fig. 3h). The cuticular foldings often correlate with wall shape: flat or concave walls are striate, convex walls are rugulate, and sharp projections are striato-knotted.

The fruits of Kitagawia species are mostly glabrous. K. komarovii (Fig. 5a,b) is the only species with minute $(10 \mu \mathrm{m})$ prickles and, occasionally, short hairs up to $50 \mu \mathrm{m}$ long. This structures are hardly visible under stereomicroscope, and the fruits were described as glabrous. The fruits of other species (including the type species $K$. terebinthacea) are glabrous and have small areas with conspicuous rugulate cuticle, the areas being either flat or slightly convex (Fig. 5c,d,e). For a long time the species were listed in the genus Peucedanum, and the genus Kitagawia was described in 1986 (Pimenov 1986). Areas with rugulate cuticle are absent in Peucedanum s. str. (Fig. 5f,g; Yildiri \& Duman 1917) and are an additional diagnostic trait of Kitagawia. Recently Pimenov (2017) published five new combinations in Kitagawia of the Chinese flora. We studied the fruits of K. praeruptora (Fig. 5h) and K. macilenta (Fig. 5i). The first species has densely pubescent fruits, the hairs being 30-70 $\mu \mathrm{m}$ long with rugulate and tuberculate cuticle, the second species has the areas with rugulate cuticle.

The cell borders on Anthriscus sylvestris (Fig. 1d,e) fruits are indistinct, and there are longitudinal rows 

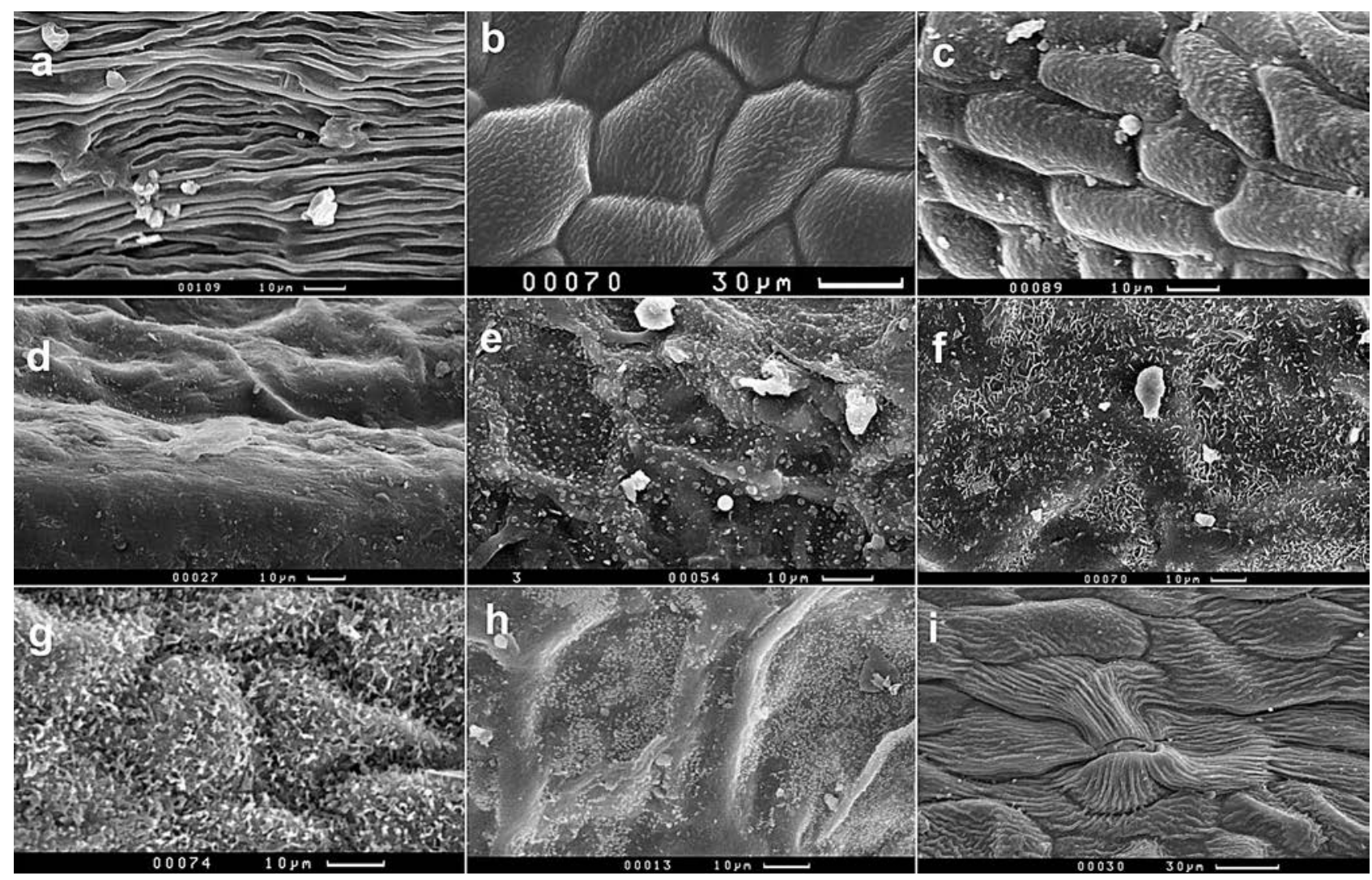

Figure 4 Cuticular foldings and epicuticular wax: a - Phlojodicarpus sibiricus, cuticle striate; b - Ostericum tenuifolium, cuticle rugulate; c - Sanicula rubriflora, cuticle tuberculate; $\mathrm{d}$ - Sium tenue, smooth wax layer; e - Cnidium monnieri, rough wax layer; $\mathrm{f}-\mathrm{h}$ - tiny wax platelts ( $\mathrm{f}-$ Bupleurum komarovianum; $\mathrm{g}$ - Bupleurum triradiatum; $\mathrm{h}$ - Glehnia littoralis); $\mathrm{i}$ - Magadania victoris, cuticle around stomata is radially striate

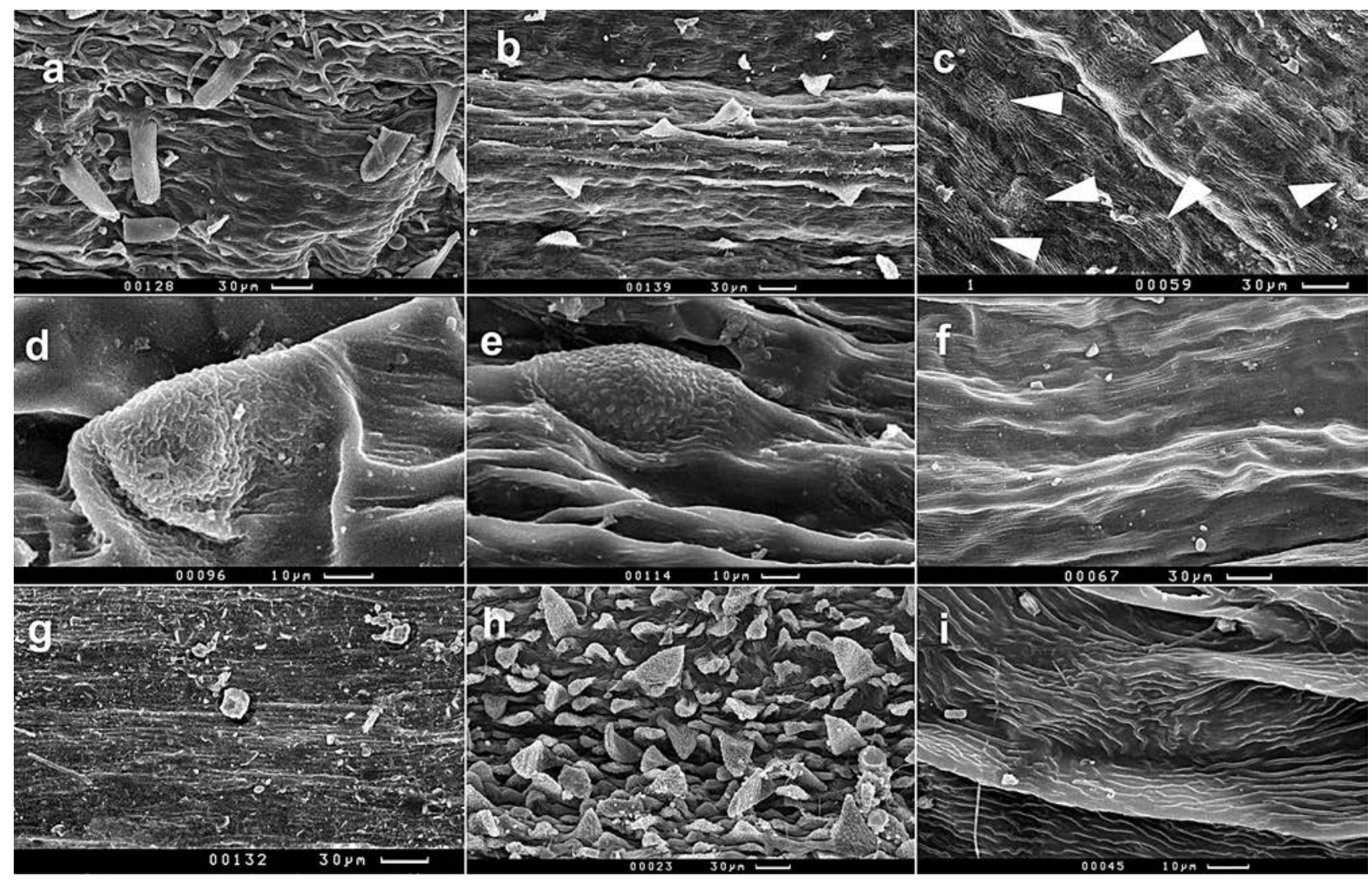

Figure 5 Kitagawia and Pencedanum: a, b - K. komarovii (a - short hairs and conical projections, b - conical projections only); c - K. terebinthacea, areas with rugulate cuticle (arrowheads); $\mathrm{d}-K$. litoralis, rugulate cuticle; $\mathrm{e}-K$. erygiifolia, rugulate cuticle; $\mathrm{f}-P$. officinale, striate cuticle; $\mathrm{g}-$ P. ruthenicum, striate cuticle; $\mathrm{h}-K$. praeruptora, densely pubescent fruit; $\mathrm{i}-\mathrm{K}$. macilenta, rugulate cuticle 
of semispherical projections. A similar microsculpture was described also in Geocaryum (Engstrand 1973) and Scandix; all the three genera belong to the tribe Scandiceae. It was noted (e.g. Yurtseva 2007) that single cell sometimes has several projections and that projections can stand either on cell borders or in the middle of a cell. At present we cannot state that one projection corresponds to one cell.

Epicuticular secretions (tertiary sculpture, "wax", Table 2) are often absent and the cuticular sculpture is clearly visible. A smooth (Fig. 4d) or rough (Fig. 4e) wax layer sometimes masks the cuticula. We observed many irregular particles on some fruit samples, but SEM images do not make it possible to distinguish wax particles from dust or other extraneous matter, so we do not classify such particles as wax. Wax characters of the species studies are shown in Table 2. In many Bupleurum species and in Glebnia, Cryptotaenia, Spuriopimpinella, and some species of Pimpinella and Angelica wax takes the form of tiny scales (Fig. 4f-h). Organic solvents and hot water removes the wax from Bupleurum fruits and some other species (Ostroumova \& Kljuykov 2015), but we could not remove the wax from Anthriscus sylvestris mericarps. For example, after soaking the fruits in acetone for 5 days at room temperature, the wax layer changed but was not removed (Fig. 1f). Wax structure most likely depends on its chemical composition.

Stomata are rare on the fruit surface, in some species we could not find any stomata, while in other species they are solitary $\left(<10\right.$ stomata per $\left.1 \mathrm{~mm}^{2}\right)$ and usually neither sunken nor raised. In Pleurospermum uralense (Fig. 3k) the stomata are located on multicellular tubercles; as to the taxa of other regions, tubercles with stomata were observed in Aulacostermum, Astrantia, and Bupleurum. Sometimes the cuticle around stomata is radially striate: Heracleum dissectum, Magadania victoris (Fig. 4i), and Tilingia ajanensis.

Crystals of calcium oxalate were revealed in the pericarp of several taxa of the Umbelliferae. The taxonomic importance of crystal shape and localization was evident as early as the end of the 19th century (Rompel 1895, Drude 1897 1898). In the subfamily Saniculoideae crystals in the form of druses are located in the mesocarp parenchyma and on the commissural region, this is true for the genus Sanicula (Fig. 6a). In the tribes Scandiceae (Osmorbiza) and Caucalideae (Torilis, Fig. 6b)), crystal are restricted to the commisure and their form is rather simple. Commissural crystals are visible to the naked eye as white powder. The most accurate test for crystals is the polarizing microscopy; SEM provides valuable information as well.

SEM also gives information on the inner structure of plant organs. Empty cells with pitted and reticulate secondary walls
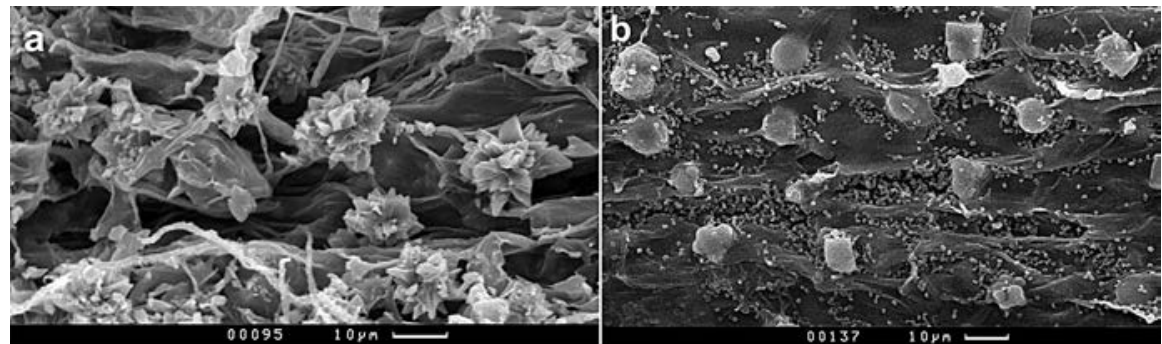

Figure 6 Crystals on the commissural side: a - Sanicula rubriflora; b - Torilis japonica are quite usual in the dry fruits of Umbelliferae, e.g. Angelica saxatilis (Fig. 7d) and Pblojodicarpus sibiricus (Fig. 7a,b,c). The outlines of fruit and endosperm transections, localization of secretory ducts, cell size, and the thickness of cell walls (Fig. $7 \mathrm{c}, \mathrm{e}, \mathrm{f})$ are easily observed.

As with many other plant characters micromorphology does not solve all the taxonomic problems.

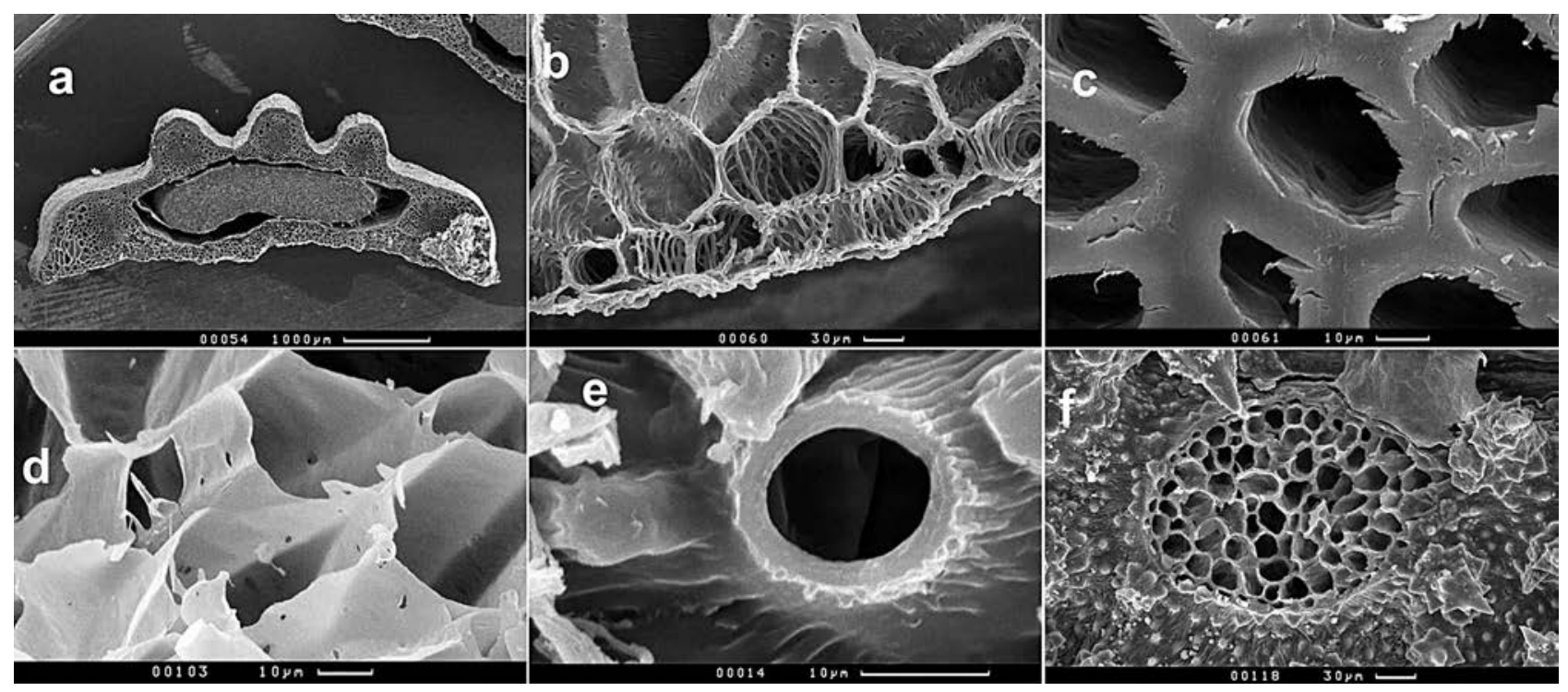

Figure 7 Inner fruit structure: a, b, c - Phlojodicarpus sibiricus (a - mericarp transection, b - parenchyma cells with pitted and reticulate walls, c - sclerenchyma); d - Angelica saxatilis, parenchyma cells with pitted walls; e - Seseli seseloides a thick-walled hair base; $\mathrm{f}$ - Torilis japonica a base of multicellular spine 
In some cases, microsculpture is a valuble source of information, while in other cases (inconspicuous cell borders, no hairs or projections, no peculiar cuticular foldings) we could not find new data for identification and taxonomic revisions.

\section{ACKNOWLEDGEMENTS}

This work is supported by the Russian Foundation for Basic Research (grants No 15-29-02748 and 16-04-00525). SEM studies are performed at the User Facilities Center of M.V. Lomonosov Moscow State University under financial support of Ministry of Education and Science of Russian Federation.

\section{LITERAT URE CITED}

Al-Eisawi, D. \& S.L. Jury 1988. A taxonomic revision of the genus Tordylium L. Botanical Journal of the Linnean Society 97:357-403.

Barthlott, W. 1981. Epidermal and seed surface characters of plants: systematic applicability and some evolutionary aspects. Nordic Journal of Botany 1981(1): 345-355.

Barthlott, W. \& N. Ehler 1977. Raster-Elektronenmikroskopie der Epidermisoberflächen von Spermatophyten. Tropische und subtropische Pflanzenwelt 19:367-467.

Downie, S.R., K. Spalik, D.S. Katz-Downie \& J.-P. Reduron 2010. Major clades within Apiaceae subfamily Apioideae as inferred by phylogenetic analysis of $n r \mathrm{DNA}$ ITS sequences. Plant Diversity and Evolution 128:111-136.

Drude, O. 1897-1898. Umbelliferae. In: Die natürlichen Pflanzenfamilien, Bd. 3, Hf. 8, (A. Engler, K.Prantl, eds), pp. 49-192, Wilheln Engelmann, Leipzig.

Duran, A., B. Doğan, H. Duman, E. Martin, M. Öztürk \& Ö Çetin 2010 Taxonomic studies on the genus Rhabdosciadium (Apiaceae) with particular reference to Turkish species and their relationships with some closely related genera. Biologia 65(3): 451-458.

Duran, A., M. Öztürk \& H. Ay 2011. Bilacunaria anatolica sp. nov. (Apiaceae) from southwest Anatolia, Turkey. Nordic Journal of Botany 29:652-659.

Duran, A., L. Behçet \& M. Öztürk. 2015. Diplotaenia bingolensis (Apiaceae), new species from east Anatolia, Turkey. Plant Systematics and Evolution 301:467--478 DOI 10.1007/s00606-014-1086-9

Engstrand, L. 1973. Generic delimitation of Bunium, Conopodium and Geocaryum (Umbelliferae). Botaniska Notiser 126 (2):146-154.

Fedoronchuk, N.M. 1983. Systematics, geography and evolution of the genera Trinia, Rumia u Ledebouriella. Naukova dumka, Kiev, 160 pp. (in Russian). [Федорончук Н.M. 1983. Систематика, география и фимогения родов Trinia, Rumia и Ledebouriella. Киев: Наукова Аумка.160с.].

Hesse, M., H. Halbritter, R. Zetter, M. Weber, R. Buchner, A. Frosch-Radivo \& S. Ulrich 2009. Pollen terminology. An illustrated handbook. Wien, N.Y. 259 pp.

Heywood, V.H. \& K.M.M. Dakshini 1971. Fruit structure in the Umbelliferae-Caucalideae. In: The Biology and Chemistry of the Umbelliferae (V.H. Heywood, ed.), pp. 215-232, Academic Press for the Linnean Society of London.

Menemen, Y. \& S. Jury 2001. A taxonomic revision of the genus Pastinaca L. (Umbelliferae). Israel Journal of Plant Sciences 49:67-77.

Ostroumova, T.A., M.G. Pimenov \& U.A. Ukrainskaya 2010. Micromorphological diversity of hairs and emergences on fruits in the Umbelliferae and its taxonomic value. Botanicheskii Zhurnal 95(9):1219-1231 (in Russian with English summary). [Остроумова Т.А., М.Г. Пименов, У.А. Украинская. 2010. Разнообразие микроморфологии волосков и эмергенцев на плодах зонтичных (Umbelliferae) и его таксономическое значение // Ботанический журнал. Т. 95, № 9. С. 1219-1231].

Ostroumova, T.A., M.G. Pimenov \& U.A. Ukrainskaya 2011. Fruit micromorphology in the Umbelliferae and its taxonomical significance. In: XVIII International Botanical Congress. Melbourne Australia 23-30 July 2011. Abstract book. Pp. 563-563.

Ostroumova, T.A. \& E.V. Kljuykov. 2015. Fruit structure and microsculpture in the annual species of the genus Bupleurum, section Perfoliata (Umbelliferae). Phytologia Balcanica 21(2):117-127.

Ostroumova, T.A., M.G. Pimenov, G.V. Degtjareva \& T.H. Samigullin 2016. Taeniopetalum Vis. (Apiaceae), a neglected segregate of Peucedanum L., supported as a remarkable genus by morphological and molecular data. Skvortsovia 3(1):20-44.

Pimenov, M.G. 1986 Kitagawia - a new asiatic genus of the family Umbeliferae. Botanicheskii Zhurnal 71(7):942-949 (in Russian). [Пименов М.Г. 1986. Kitagawia - новый азиатский род семейства Umbelliferae // Ботанический журнал 71(7):942-949].

Pimenov, M.G. 2017. Updated checklist of Chinese Umbelliferae: nomenclature, synonymy, typification, distribution. Turczaninowia 20(2):106-239.

Pimenov, M.G. \& T.A.Ostroumova 2012. Umbelliferae of Russia. KMK Scientific Press, Moscow, 477 pp. (in Russian with English summary). [Пименов М.Г., Остроумова Т.А. 2012. Зонтичные (Umbelliferae) России. Москва, КМК. 477c.].

Plunkett, G.M., M.G. Pimenov, J.-P. Reduron, E.V. Kljuykov, B.-E. van Wyk, T.A. Ostroumova, M.J. Henwood et al. 2018. Apiaceae. In: Families and Genera of Vascular Plants, vol. 15 (K. Kubizky, ed.). (submitted).

Rompel, S.J. 1895. Krystalle von Calciumoxalat in der Fruchtwand der Umbelliferen und ihre Verwertng für die Systematik. Sitzungsberichte der mathematisch-naturwissenschaftlichen Classe der Kaiserlischen Akademie der Wissenschaften 104(1):417-474.

Spalik, K., A. Wojewódzka \& S.R. Downie (2001) The delimitation of genera in Apiaceae with examples from Scandiceae subtribe Scandicinae. Edinburgh Journal of Botany 58:331-346.

Tamamschjan, S.G. \& M.G.Pimenov 1987. The genus Eryngium L. (Apiaceae) in Transcaucasus, Middle Asia, Iran, and Afghanistan. Flora, Vegetation and Plant Resources of Armenian SSR 10:26-49 (in Russian with Armenian summary). [Тамамшян С.Г., Пименов М.Г. 1987. РоА Eryngium L. (Apiaceae) в Закавказье, Средней Азии, Иране и Афганистане // ФАора, растительность, растительные ресурсы Армянской ССР. Т. 10. С. 26-49].

van Wyk, B.-E. \& P.M. Tilney 2008. A new species of Lichtensteinia (Apiaceae). South African Journal of Botany 74: 757-760.

Wang, H.-C., X.-M. Zhou, H. Sun \& Y.-H. Wang 2013. Acronema crassifolium sp. nov. (Apiaceae), a distinct new species from Yunnan, southwest China. Phytotaxa 87(3):39-44.

Yildiri, H. \& H. Duman 2017. Peucedanum guvenianum (Apiaceae), a new species from West Anatolia, Turkey. Turkish Journal of Botany 41:600-608. 